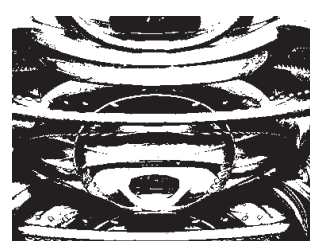

doi:10.5559/di.22.1.01

\title{
PRICE SENTIMENT OF CROATIAN CONSUMERS: THE UPWARD BIAS OF COLLECTIVE MEMORIES
}

Petar SORIĆ, Miriana ČIŽMEŠIJA

Faculty of Economics and Business, Zagreb

UDK: 336.1(497.5):336.-748.12

Izvorni znanstveni rad

Primljeno: 9. 12. 2011.

This paper touches upon the differences between inflation perceptions and expectations of different socio-demographic groups (with respect to age, gender, income and education), a topic that has not so far been adequately represented in Croatia. The analysis is based on a unique dataset obtained from Consumer Surveys (conducted by the Croatian National Bank). Indicators of perceived and expected inflation are estimated in two separate ways: as direct responses of individual consumers and as the balances of responses to the questions about the perceived and anticipated inflation rates. Both observed measures reveal significant differences in the inflation sentiment between the well-off and the socio-economically disadvantaged consumers. The divergence is particularly pronounced with respect to household income, while the differences between male and female respondents are negligible. Psychological explanations of these differences are found in behavioural heuristics. The availability heuristic is proven to be valid through the phenomenon that older people (who have dealt with several hyperinflation episodes in their adult life) produce significantly higher inflation sentiment. The associativeness heuristic also performs well, having in mind that Croatians obviously relate today's rising economic uncertainty with hyperinflation (as in the early 1990s), opposing both real economic trends and economic theory.

Keywords: inflation perceptions and expectations, heuristics, consumer sentiment

$\triangle$ Petar Sorić, Faculty of Economics and Business, Department of Statistics, Trg J. F. Kennedya 6, 10000 Zagreb, Croatia. E-mail: psoric@efzg.hr 


\section{INTRODUCTION AND MOTIVATION}

Economic agents' attitudes, perceptions and expectations vis$-\grave{a}$-vis their economic environment constitute a crucial determinant of their actual decisions and actions. Therefore it is of the essence to adequately explore the formation process of economic perceptions and expectations. Special emphasis here is given to analyzing the inflation sentiment. ${ }^{1}$

The necessity of exploring consumers' inflation sentiment stems from both theoretical and empirical grounds. Microeconomic theory postulates that individual demand is determined by the consumer's budget and market prices, taking as given that consumers indeed perceive price changes correctly (Antonides, 2008). Nevertheless, empirical studies often contradict this assumption, revealing a significant gap between real and perceived inflation (as "seen" by the consumers. ${ }^{2}$ Perhaps the most striking example is the disproportionally high perceived inflation in the Euro area (EA) due to the Euro cash changeover in January 2002 (Brachinger, 2008). Such discrepancy has raised the question of HICP non-credibility, regarding the fact that it is evidently not accepted by the public as a realistically founded measure of aggregate price changes (Antonides, 2008).

On the other hand, inflation expectations play a pivotal role in the areas of monetary policy, consumer behaviour and the theory of the firm. If companies expect the aggregate price level to increase in some future period, they will raise the prices of their products and services today. Consequently, an increase in expected inflation induces real inflationary pressures.

Consumers attach a significant weight to inflation in determining their consumption volume. If consumers expect a significant decline of prices in a certain future period, they will postpone consumption. On the other hand, if they expect a price growth, the result will probably be a consumption boost in the period of forming the expectations (Evans \& Honkapohja, 2001).

Yet the very earliest studies of consumers' price perceptions have raised the question of economic agents being able to perceive price changes at all (Gabor \& Granger, 1961). The authors highlight that only around $82 \%$ of the respondents had any recollection of the prices of recently bought groceries. Even more contradicting to the prevailing concept of homo economicus, they find that merely $51.1 \%$ of examinees were able to correctly reminisce the prices of bought goods. Such inferences have initiated an entire series of price perception studies, and have enforced the development of a novel science branch: psychophysics of prices. Psychophysics is mainly focused on analyzing the influence of "physical" stimuli (real 
DRUŠ. ISTRAŽ. ZAGREB GOD. 22 (2013), BR. 1 STR. $1-21$

SORIĆ, P., ČIŽMEŠIJA, M.: PRICE SENTIMENT... prices) on the human mental sensation (price perceptions) created by them (see e.g. Antonides, 2008).

The aim of this paper is to shed some light on the heterogeneity of Croatian consumers in terms of inflation perceptions and expectations. Relying on a unique dataset gathered from the Croatian consumer survey, differences are tested between inflation sentiments of consumer groups, identified through relevant socio-demographic characteristics: gender, income, educational attainment and age. The way that real inflationary movements feed into consumers' perceptions and expectations is particularly important in Croatia. Namely, the Croatian economy has recorded several hyperinflation episodes in its history (Anušić, Rohatinski, \& Šonje, 1995). In that sense, if a critical mass of people with excessive inflation sentiment is established; such views could induce real inflationary pressures and distort the current monetary policy regime in Croatia. On the microeconomic level, pronounced differences in the inflation sentiment of different socio-demographic groups would entail divergent marketing approaches and different retail trade policies for each specific consumer group.

In order to provide plausible explanations for such discrepancies, several behavioural heuristics are tested. To be more specific, the hypotheses of this paper (in line with the prevailing conclusions from related international studies) are:

H1: Croatian consumers with considerable hyperinflation experiences produce significantly higher inflation sentiment than those from the younger age groups (in line with the availability heuristic).

H2: Socio-economically disadvantaged consumers (less vs. more educated and the poor vs. the wealthy) are more upwards biased in assessing actual inflation tendencies.

H3: Women tend to produce significantly higher inflation sentiment than men.

H4: The associativeness heuristic compels the consumers to produce higher inflation sentiment in the times of economic hardship.

\section{CONSUMER SURVEYS IN CROATIA: METHODOLOGICAL ISSUES}

Consumer surveys (CS) are qualitative examinations aimed at expressing consumers' views regarding past, present and future conditions of relevant variables from their economic surroundings. For example, CS are usually focused on variables such as unemployment, the general economic situation in the country, financial position of the respondents' household, etc. 
DRUŠ. ISTRAŽ. ZAGREB GOD. 22 (2013), BR. 1, STR. 1-2

SORIĆ, P., ČIŽMEŠIJA, M.: PRICE SENTIMENT..
This study is particularly interested in the consumers' judgments about Croatian inflation movements.

CS have been put into practice for the first time in 1946 by George Katona at the University of Michigan (Campbell \& Katona, 1946). Shortly after that, the surveys have been introduced in various European countries, emphasizing the necessity of methodological unification in order to ensure comparability of results at an international level. Hence, the Joint Harmonized EU Programme of Business and Consumer Surveys has been initiated in 1961. At the moment, the Programme comprises all current EU member and candidate countries, including Croatia. The survey methodology in Croatia (sampling, treatment of non-response, weighting etc.) is fully adjusted with the EU standards and of comparable quality to any EU member state (see European Commission (2007) for a detailed description of the used methodological framework).

The empirical administering of CS in Croatia has been assigned to the Croatian national bank (CNB), and has been continually conducted on a monthly basis since May 2005.

Surveys are carried out through field research via interviews. The sample comprises 1000 consumers each month, whereby the respondents partially vary in each period. According to the EU methodology, the sample is selected by stratifying the population in terms of regions and settlement size. Afterwards, quota sampling is implemented, using gender and age as target variables (for more details about the statistical methodology used in CS, see European Commission, 2007). Each month of the observed period (May 2005 to October 2011 in this study), the respondents examined by the CS are separated into several subgroups with regards to relevant socio-demographic variables: gender (female and male), age (15-29, 30-49, $50-64$ and 65 or more), education (primary, secondary and further) and household income (four quartile income groups: $Q_{1}$ to $Q_{4} ; Q_{1}$ being the wealthiest respondents). ${ }^{3}$

Questions in the CS are closed-ended and of qualitative nature. Two specifically interesting questions for the sake of this study are given as follows.

Q5. How do you think that consumer prices have developed over the last 12 months?

They have...

(1) risen a lot

(2) risen moderately

(3) risen slightly

(4) stayed about the same

(5) fallen

(N) don't know. 
DRUŠ. ISTRAŽ. ZAGREB GOD. 22 (2013), BR. 1 STR. 1-21

SORIĆ, P., ČIŽMEŠIJA, M.: PRICE SENTIMENT...
Q6. By comparison with the past 12 months, how do you expect that consumer prices will develop in the next 12 months? They will...

(1) increase more rapidly

(2) increase at the same rate

(3) increase at a slower rate

(4) stay about the same

(5) fall

(N) don't know.

For a complete review of the CS questions in Croatia see Čižmešija (2008).

Since the observed questions are purely qualitative, certain methodological steps need to be taken to obtain exact quantitative estimates of consumers' inflation sentiment. In order to obtain individual consumers' sentiment of inflation perceptions and expectations, two additional questions are being asked in Croatian CS continually since May 2005. These questions are given as follows.

Q5.1. If question 5 was answered by $1,2,3$, or 5 :

By how much percent do you think that consumer prices have gone up/down over the past 12 months? (Please give a single figure estimate).

Consumer prices have increased by $\%$ / decrease by $\%$.

Q6.1. If question 5 was answered by $1,2,3$, or 5 :

By how much percent do you expect consumer prices to go up/down in the next 12 months? (Please give a single figure estimate).

Consumer prices will increase by $\%$ / decrease by $\%$.

In that way, a measure of perceived and expected inflation is gathered from each individual examinee.

A different approach would be to obtain an aggregate measure of consumers' inflation sentiment. According to the EU methodology, the simplest (and the most widely used) approach is to estimate the balance statistics of responses to questions 5 and 6 (European Commission, 2007). The balance of responses is defined as a weighted difference of positive and negative response shares, and is calculated by the following equation:

$$
B=(P P+0.5 P)-(0.5 M+M M),
$$

where $B$ is the balance statistics, $P P$ is the percentage of respondents that chose the extremely positive answer (risen a 
DRUŠ. ISTRAŽ. ZAGREB GOD. 22 (2013), BR. 1, STR. 1-2

SORIĆ, P., ČIŽMEŠIJA, M.: PRICE SENTIMENT.. lot/increase more rapidly), $P$ is the share of examinees that replied positively (risen moderately/increase at the same rate), $M$ is the percentage of negative answers (risen slightly/increase at a slower rate) and $M M$ is the percentage of extremely negative answers (fallen/fall). ${ }^{4}$

In accordance with that, response balances of questions 5 and 6 are also employed here to represent consumers' inflation perceptions and expectations (respectively). The response balance for questions 5 and 6 (perc and exp hereinafter) is calculated monthly, enabling the exact measuring of consumers' inflation sentiment both on the aggregate level and for the specific socio-demographic subgroups.

\section{SOCIO-DEMOGRAPHIC ASPECTS OF INFLATION SENTIMENT}

One of the major breakthroughs of Gabor and Granger's pioneer work (1961) is the finding that, with an increase in income, respondents pay less and less attention to groceries prices. Thus the poorest group of respondents was able to reminisce $80.3 \%$ of prices, while the wealthiest one remembered merely $63.3 \%$ of prices. ${ }^{5}$ Further studies have accentuated the heterogeneity of consumers' price sentiment with respect to not only income, but also other socio-demographic characteristics such as gender, educational attainment, (un)employment, age, etc.

Bryan and Venkatu (2001a) focus on CS results gathered from the Federal Reserve Bank of Cleveland, in order to explore the differences in consumers' price perceptions and expectations between different socio-demographic groups. The authors divide the sample into homogenous groups vis-à-vis gender, race (white/nonwhite), marital status, educational attainment (elementary, high school and further), income (five income quintiles) and age (6 age groups). The most striking conclusion is that literally all observed groups considerably overestimate inflation developments (both in terms of inflation perceptions and expectations). However, the results between groups seem rather heterogeneous. Women's inflation perceptions and expectations tend to be significantly higher than those of men. Similarly, married/white/highly educated respondents generate less intensive inflation sentiment than the single/nonwhite/ less educated ones. With respect to income, both inflation perceptions and expectations almost linearly decline with a rise in wealth. Finally, age segregation of consumers reveals that the youngest (18-25) and the retirement group (65+) see inflation as a more intense threat to their purchasing power than middle-aged groups.

Bryan and Venkatu (2001b), relying on the same CS, pay even more attention to the difference in inflation sentiments 
DRUŠ. ISTRAŽ. ZAGREB GOD. 22 (2013), BR. 1 STR. $1-21$

SORIĆ, P., ČIŽMEŠIJA, M.: PRICE SENTIMENT.. between men and women. The authors postulate that the stated sentiment gap can partly be attributed to other socio-economic factors apart from gender. However, dummy regression analysis on survey micro-data has shown that, even when educational level, age, race and income are taken into account, women still perceive and expect considerably higher inflation than men.

Palmqvist and Strömberg (2004) study the inflation sentiments of different socio-demographic groups on the basis of Swedish CS. The authors also utilize dummy variables regressions on micro-data. The obtained conclusions are, for the most part, in line with those of Bryan and Venkatu (2001a, b). Nearly all dummy variables were proven to be significant, with the greatest differences found between gender and income groups. The only characteristic that failed to confirm significant differences between groups is work. ${ }^{6}$ In addition to the so far analyzed variables, Palmqvist and Strömberg (2004) also explore the effect of housing and children in household. It is pointed out that respondents with children/in tenant owned housing perceive and expect inflation to be significantly higher than consumers without children/in rented housing.

Lindén (2005) explores consumers' inflation sentiment gathered from the Harmonized CS on the EA level. Applying simple descriptive statistics on aggregate response balances for the period of 1991-2005, the author firmly corroborates Palmqvist and Strömberg's (2004) inferences. The only exception is that, on average, EA consumers tend to experience inflation more and more (too)intensively as they grow older.

Pfajfar and Santoro (2008) highlight three major sources of consumers' heterogeneity in terms of inflation expectations. First of all, economic agents may implement various theoretical models of expectations (such as rational or adaptive expectations). Secondly, individual consumers base their inflation judgments on different information sets (different levels of (macro)economic literacy, diverse awareness levels of price changes and different methodological knowledge about the sole calculation of aggregate price indices). Lastly, economic agents can have fairly dissimilar capacities of processing economic information. With that in mind, Pfajfar and Santoro (2008) analyze inflation expectations rationality for different socio-economic groups, relying on the CS conducted by the University of Michigan. The authors again identify income, education and gender as crucial predictors of consumers' inflation sentiment. The interdependence of age and inflation judgments once more has not been unambiguously clarified. Namely, both inflation perceptions and expectations seem to linearly fall with consumers' age, contradicting every previously mentioned paper. A common conclusion, inherent to each analyzed 
DRUŠ. ISTRAŽ. ZAGREB GOD. 22 (2013), BR. 1, STR. 1-2

SORIĆ, P., ČIŽMEŠIJA, M.: PRICE SENTIMENT... socio-demographic group, is that consumers positioned in the centre of the response distribution are rational. Consumers on the left and right-hand side of the median cannot be characterized as rational.

At this point, several conclusions can be drawn. Firstly, all observed consumer groups tend to overemphasize price developments. However, the socio-economically disadvantaged groups (on average) experience inflation being significantly higher than those who are well-off. Secondly, there is a consensus in the literature about income, gender and education being significant predictors of consumers' ability to assess past and future inflation. The only ambiguous variable is age, revealing somewhat contradictory relationships with inflation sentiment.

\section{BEHAVIOURAL CONCEPTS AS A FOUNDATION OF THE INFLATION SENTIMENT GENERATING PROCESS}

Neoclassical economic theory mainly describes economic agents as rational decision makers who base their actions on the entire accessible information set through a statistically-based decision-making model. However, empirical research has, more than often, proved that such assumptions are too restrictive and unrealistic. In the context of inflation sentiment, it is well documented in the literature that consumers are often not able to fully take into account all available economic information, nor does their level of economic literacy always enable them to form rational inflation perceptions and expectations. E.g., Gramlich (1983) offers empirical evidence that neither US consumers nor professional economists are able to produce unbiased estimates of future inflation rates. Forsells and Kenny (2004) conclude that, although EA consumers do not produce considerable inflation forecasting errors, they are not capable of noticing changes in the monetary aggregates or interest rates while forming inflation expectations. Kokoszczyński, Łyziak and Stanisławska (2006) also find significant prediction errors between the expected and actual inflation rates for Polish and Czech consumers. And finally, Sabrowski (2008) offers additional insights to the non-rationality of German inflation expectations for the same socio-demographic subgroups as used in this study.

Because of such discrepancies, a concept of behavioural economics has been introduced, as a mainly psychologically-based approach. ${ }^{7}$ In that way, the accent is placed on the cognitive processes behind the sole inflation sentiment formation, which could be particularly useful to discern the observed heterogeneity of various socio-demographic groups.

Behavioural economics implies that economic agents assign probabilities to future events in a purely subjective (non- 
DRUŠ. ISTRAŽ. ZAGREB GOD. 22 (2013), BR. 1 STR. $1-21$

SORIĆ, P., ČIŽMEŠIJA, M.: PRICE SENTIMENT.. -statistical) manner (Gnan, Langthaler, \& Valderama, 2010). In line with that, behavioural literature emphasizes several heuristics (cognitive algorithms) that are able to offer useful insights and reveal the psychological foundations that predetermine the way consumers perceive inflation.

Kahneman and Tversky (1974) introduced the availability heuristic, a concept implying that agents determine the likelihood of some event according to the facility of recollecting a similar event from their memory. To be specific, the more experience consumers have with high inflation during their life, the higher is the probability that their answer to questions 5 and 6 of the CS will be "risen a lot" and "increase more rapidly". Hence, the availability heuristic would initiate an a priori high inflation sentiment for consumers who experienced the hardships of hyperinflation during the 1980s and in the first half of the 1990s.

The validity of this concept has not so far been questioned in Croatia, but it has been empirically confirmed for the UK. Lombardelli and Saleheen (2003) found that inflation experience throughout the respondents' adult life has a statistically significant impact on their inflation sentiment. The availability heuristic can also be applied to elucidate the "Euro induced inflation" in the EA during 2002. With the intent to explain that phenomenon, an entire new research direction has evolved, postulating that consumers perceived inflation as unrealistically high due to a rise in the prices of the frequently bought goods and services. Namely, in the wake of the Euro's introduction, some market segments took advantage of the mandatory price conversion from former national currencies to Euro to significantly boost their prices. For example, considerable growth has been recorded for food, restaurants and cafés prices (Eurostat, 2003). According to the availability heuristic, consumers misinterpreted the local price growth as the global (aggregate) inflation rate because of their frequent experiences with buying essential goods such as food and drinks.

Mullainathan (2002) introduced a very similar concept, called the associativeness heuristic. Such a model hypothesizes that the resemblance of current or expected future events to some past event makes it easier for the agents to recollect and magnifies their sentiment of that event. The problem that arises here is that agents can relate economic events to some (possibly) trivial incidents. Consequently, even such irrelevant information can be incorporated into consumers' inflation expectations. For example, consumers could associate a fall in economic activity (such as the one in the early 1990s due to the war devastations) with hyperinflation. Each future recession could then induce the consumer to perceive the current inflation rate as very high or expect a price hike in the following year. 
DRUŠ. ISTRAŽ. ZAGREB GOD. 22 (2013), BR. 1, STR. 1-2

SORIĆ, P., ČIŽMEŠIJA, M.: PRICE SENTIMENT..
Carroll (2001) introduced an epidemiological model of forming macroeconomic expectations, which assigns a pivotal role to economic news. Economic agents update their information set via the media and adjust their expectations to correspond to the ones of economic professionals. Nevertheless, according to the confirmation bias heuristic, agents do not fully take into account the newly obtained information (or interpret them in a biased way); in order to corroborate their prior expectations (Gnan et al., 2010.). This was also one of the approaches used to clarify the "Euro induced inflation" phenomenon. Traut-Mattausch, Schulz-Hardt, Greitemeyer and Frey (2004) were the first to empirically demonstrate that (too) high inflation perceptions upon introduction of the Euro are conditioned by the beforehand existing expectations that the Euro will cause an inflation boom. Traut-Mattausch et al. (2004) conducted an experiment by dividing the examinees into three groups. Every group was shown a restaurant menu with prices denominated in Deutsche Marks (DM), after which each group was given a separate menu with prices in Euros. The prices given to the first group were converted correctly, the second group was presented 15\% too high prices, and the last group was confronted with 15\% too low prices. Surprisingly, all three groups had upward biased price perceptions, even the one with the prices in Euros that were 15\% lower than those in DM. The authors explained these findings by postulating that consumers' prior inflation expectations significantly feed into their inflation perceptions.

Kahneman and Tversky (1974) also introduced the anchoring and adjustment heuristic, a term they used to explicate a cognitive process in which agents form their expectations on the basis of the initial value (anchor) of the observed variable. If economic agents are involved in making a judgment about inflation, they are basically anchoring their perceptions/expectations towards the inflation value targeted by the central bank. CNB is not implementing the inflation targeting monetary regime, but this concept can nevertheless be applied to Croatian consumers. Namely, ever since the last Stabilization Programme in 1993, Croatia has been recording rather stable inflation rates. In that sense, a stable macroeconomic environment enables the consumers to correctly perceive current inflation, as well as to predict its future values. The role of consumers' education, economic literacy and general economic awareness is particularly emphasized in that context. That is to say, more educated people should in general have more intensive exposure to economic facts and, in turn, have smaller inflation prediction and expectation errors.

Blanchflower and Kelly (2008) gave the initial impulse in relating the accuracy of inflation perceptions (expectations) to the level of economic literacy. Namely, the authors justified 
DRUŠ. ISTRAŽ. ZAGREB GOD. 22 (2013), BR. 1 STR. $1-21$

SORIĆ, P., ČIŽMEŠIJA, M.: PRICE SENTIMENT.. the biased inflation sentiment in the UK CS by the low level of (economic) education. Del Giovane, Fabiani and Sabbatini (2008) elaborate that thesis further by demonstrating that less educated Italians generate larger inflation perception errors than those with a university degree. Even more intriguingly, $52.9 \%$ of respondents could not differentiate between the concepts of price level and inflation, as much as $66.9 \%$ of examinees were not (even approximately) acquainted with the categories of products/services that enter the CPI, etc.

\section{EMPIRICAL RESULTS}

Bearing in mind the pronounced differences between particular socio-demographic groups in terms of inflation sentiment (as elaborated in the literature review in Section 3), the empirical analysis is based on Croatian CS results to test whether the same conclusions apply here.

Before any statistical analysis, simple arithmetic means of the time series of aggregate perceived inflation balance statistics (perc) and expected inflation balance statistics (exp) are calculated.

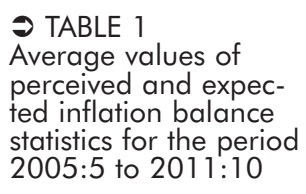

\begin{tabular}{llrl}
\hline & & Perc & Exp \\
\hline Age & $15-29$ & 44.370 & 22.89 \\
& $30-49$ & 53.89 & 30.97 \\
& $50-64$ & 57.98 & 34.01 \\
\multirow{5}{*}{ Education } & $65+$ & 55.47 & 31.09 \\
& Primary & 55.62 & 30.98 \\
\multirow{5}{*}{ Income } & Secondary & 52.43 & 29.61 \\
& Further & 45.95 & 26.41 \\
& Q1 & 47.88 & 26.90 \\
& Q2 & 53.55 & 31.05 \\
\multirow{5}{*}{ Gender } & Q3 & 56.82 & 32.85 \\
& Q4 & 58.20 & 33.59 \\
& Female & 54.55 & 30.65 \\
& Male & 51.17 & 28.82 \\
\hline
\end{tabular}

One important inference arises here: it can be concluded that the consumers are slightly more optimistic in anticipating future economic developments than they are in judging the recent ones. This is exactly the conclusion obtained by Bukovšak (2006) through analyzing consumers' attitudes about the general economic situation in Croatia.

In order to formally question whether the differences in inflation sentiment between various groups are statistically significant, the ANOVA analysis (for age, education and income) and the unpaired two-sample t-test for a difference in mean (for gender) are applied. ${ }^{8}$ 
DRUŠ. ISTRAŽ. ZAGREB GOD. 22 (2013), BR. 1, STR. 1-2

SORIĆ, P., ČIŽMEŠIJA, M.: PRICE SENTIMENT.
(1) TABLE 3

Tukey procedure (multiple comparisons) results (perc)
The results given in Table 2 clearly show that the only variable that does not reveal significant differences between its subgroups is gender. Although women (in line with previous studies) generate higher inflation sentiment than men (see Table 1), the difference is purely random. Such deviations from the research of Bryan and Venkatu (2001a, b) or Palmqvist and Strömberg (2004) arise from the fundamental differences in the relative position of women on the Croatian and USA labour market. Namely, in former socialist countries, such as Croatia, gender (wage) equality was a strongly proclaimed policy goal. As a result of that, the Croatian gender wage gap is still extremely low today, as it was in the former system. E.g., Nestić (2010) reports the raw gender wage gap in 2008 being equal to merely $10.5 \%$. For comparison, the same gap in EU-15 in 2008 was as much as $18 \%$.

\begin{tabular}{lll}
\hline & Test statistics & \\
\cline { 2 - 3 } Variable & Perc & Exp \\
\hline Age & $F=13.337^{* * *}$ & $F=26.229^{* * *}$ \\
Education & $F=8.541^{* *}$ & $W=5.008^{* *}$ \\
Income & $F=7.652^{* * *}$ & $F=9.039^{* * *}$ \\
Gender & $t=1.488$ & $t=1.446$
\end{tabular}

Note: $F$ stands for the one-way ANOVA test statistics, $W$ stands for the Welch test statistics (employed where the Levene's test did not prove adequacy in terms of homogeneity of variances). ${ }^{*} \mathrm{p}<0.05 ;{ }^{* *} \mathrm{p}<0.01 ;{ }^{* *} \mathrm{p}<0.001$

\begin{tabular}{|c|c|c|c|c|c|}
\hline \multirow{2}{*}{$\begin{array}{l}\text { Variable } \\
\text { Age }\end{array}$} & \multirow[t]{2}{*}{$\begin{array}{l}\text { Reference } \\
\text { category }\end{array}$} & \multicolumn{4}{|c|}{ Mean differences between the reference and comparative categories } \\
\hline & & $15-29$ & $30-49$ & $50-64$ & $65+$ \\
\hline & $15-29$ & - & $-9.517^{* * *}$ & $-13.608^{* * *}$ & $-11.097^{* * *}$ \\
\hline & $30-49$ & $9.517^{* * *}$ & - & -4.091 & -1.581 \\
\hline & $50-64$ & $13.608^{* * *}$ & 4.091 & - & 2.511 \\
\hline & $65+$ & $11.097^{* * *}$ & 1.581 & -2.511 & - \\
\hline \multirow[t]{4}{*}{ Education } & & Primary & Secondary & Further & \\
\hline & Primary & - & 3.186 & $9.666^{* * *}$ & \\
\hline & Secondary & -3.186 & - & $6.480^{*}$ & \\
\hline & Further & $-9.666^{* * *}$ & $-6.480^{*}$ & - & \\
\hline \multirow[t]{5}{*}{ Income } & & $Q_{1}$ & $Q_{2}$ & Q3 & $Q_{4}$ \\
\hline & $Q_{1}$ & - & -5.668 & $-8.933^{* *}$ & $-10.323^{* * *}$ \\
\hline & $Q_{2}$ & 5.668 & - & -3.265 & -4.655 \\
\hline & $\widetilde{Q}_{3}$ & $8.933^{* *}$ & 3.265 & - & -1.390 \\
\hline & $Q_{4}$ & $10.323^{* * *}$ & 4.655 & 1.390 & - \\
\hline
\end{tabular}

${ }^{*} \mathrm{p}<0.05 ;{ }^{* *} \mathrm{p}<0.01 ;{ }^{* *} \mathrm{p}<0.001$ 
DRUŠ. ISTRAŽ. ZAGREB GOD. 22 (2013), BR. 1 STR. $1-21$

SORIĆ, P., ČIŽMEŠIJA, M.: PRICE SENTIMENT...

(1) TABLE 4

Tukey procedure (multiple comparisons) results (exp)

\begin{tabular}{|c|c|c|c|c|c|}
\hline \multirow{2}{*}{$\begin{array}{l}\text { Variable } \\
\text { Age }\end{array}$} & \multirow[t]{2}{*}{$\begin{array}{l}\text { Reference } \\
\text { category }\end{array}$} & \multicolumn{4}{|c|}{ Mean differences between the reference and comparative categories } \\
\hline & & $15-29$ & $30-49$ & $50-64$ & $65+$ \\
\hline & $15-29$ & - & $-8.084^{* * *}$ & $-11.121^{* * *}$ & $-8.204^{* * *}$ \\
\hline & $30-49$ & $8.084^{* * *}$ & - & -3.037 & -0.120 \\
\hline & $50-64$ & $11.121^{* * *}$ & 3.037 & - & 2.916 \\
\hline & $65+$ & $8.204^{* * *}$ & 0.120 & -2.916 & - \\
\hline \multirow[t]{4}{*}{ Education } & & Primary & Secondary & Further & \\
\hline & Primary & - & 1.368 & $4.565^{* *}$ & \\
\hline & Secondary & -1.368 & - & 3.196 & \\
\hline & Further & $-4.565^{* *}$ & 3.196 & - & \\
\hline \multirow[t]{5}{*}{ Income } & & $Q_{1}$ & $Q_{2}$ & Q3 & $Q_{4}$ \\
\hline & $Q_{1}$ & - & $-4.155^{*}$ & $-5.947^{* * *}$ & $-6.688^{* * *}$ \\
\hline & $\mathrm{Q}_{2}$ & $4.155^{*}$ & - & -1.792 & -2.532 \\
\hline & Q3 & $5.947^{* * *}$ & 1.792 & - & -0.741 \\
\hline & $Q_{4}$ & $6.688^{* * *}$ & 2.532 & 0.741 & - \\
\hline
\end{tabular}

${ }^{*} \mathrm{p}<0.05 ;{ }^{* *} \mathrm{p}<0.01 ;{ }^{* *} \mathrm{p}<0.001$
It would also be interesting to inspect the possible differences between individual subcategories for each socio-demographic variable. The results of Tukey post-hoc multiple comparisons are given in Tables 3 and 4 .

It is apparent that the differences in the inflation perceptions are most pronounced between the extremely opposite socio-demographic groups: the well-educated vs. the less-educated and the wealthiest vs. the poorest. The age segregation yielded two distinctive clusters: younger and older than 30 .

The exact same patterns are also obvious for inflation expectations.

A general explanation for diverging inflation sentiments in various groups is that the groups are rather dissimilar in terms of the market baskets they purchase. Namely, each consumer faces the prices of the goods he/she regularly purchases on a daily basis. These prices need not correspond to the national average prices, as measured by the aggregate price index. This question was also raised by Bryan and Venkatu (2001a), who conclude that the observed heterogeneity can only partially be attributed to different structures of the market baskets.

Therefore, in elucidating the differences with respect to age, the availability heuristics must be underlined as a crucial determinant. Namely, it is clearly visible that the consumers with vivid hyperinflation experiences (aged 30 and more) generate notably higher inflation sentiment than the 15-29 age 
DRUŠ. ISTRAŽ. ZAGREB GOD. 22 (2013), BR. 1, STR. 1-2

SORIĆ, P., ČIŽMEŠIJA, M.: PRICE SENTIMENT.. group. Very intriguingly, the most pessimistic group (both in terms of perc and exp) consists of the pre-retirement consumers (50-64 years of age). These conclusions can therefore be related to the general notice that middle-aged Croatians record the lowest levels of life satisfaction (Penezić, 2006). Also, Malešević Perović (2010) finds that life satisfaction reaches its lowest point in Croatia approximately at the age of 58 .

The discrepancies in the inflation sentiment seem to be most pronounced with respect to income. A general tendency is noticeable that consumers, with a rise in their income, perceive inflation to be smaller and smaller (Table 1). This finding strongly corroborates the conclusions of Gabor and Granger (1961), who observed the same pattern in terms of price recollection. Obviously, the accumulation of consumers' nominal wealth diverts them from paying attention to price movements.

With regards to education, it is evident that the difference between the inflation sentiment of consumers with primary and secondary school education is not significant. Therefore, the effect of education on the inflation sentiment (in the sense of Blanchflower and Kelly) is observable only at the high educational level. Apart from the highlighted behavioural heuristics, some cognitive theories should also be mentioned as possible explanations for the observed divergences. For example, the concept of bounded rationality (Simon, 1955) brings biased inflationary sentiment in relation to objective restrictions such as the information availability or the economic agents' cognitive capacity to process this information. Namely, if the economic agents fully acknowledge the costs of updating their information set, they might prefer to intentionally make decisions based on incomplete information. Also, the sticky information model (Mankiw \& Reis, 2002) puts forward the argument that economic news spreads through the population rather slowly. Within such an epidemiological model, the central role is assigned to economic professionals and economically educated agents. Both mentioned cognitive theories could serve as plausible explanations for the observed divergence between consumers with different educational attainment.

In order to corroborate these aggregate findings, the analysis should also be conducted on individual consumers' answers. Let perc_ind and exp_ind be the individual answers to the questions Q5.1 and Q6.1 in the CS. Since these answers represent cross-section observations (not time series data), it is obligatory to observe them in a specific time period (month). The road taken here is to select a month that is not characterized by any atypical inflationary pressures or high economic uncertainty. 
DRUŠ. ISTRAŽ. ZAGREB GOD. 22 (2013), BR. 1 STR. 1-21

SORIĆ, P., ČIŽMEŠIJA, M.: PRICE SENTIMENT..

? TABLE 5 Consumers' inflation sentiment as a function of socio-demographic characteristics
The actual inflation dynamics is inspected throughout the whole observed period, and an average CPI monthly inflation rate of 3.04\% is found. March 2006 (with the yearly inflation rate of $2.99 \%$ ) is identified as a representative month, and responses from that month are used to estimate the dummy regression of the following form:

$$
\operatorname{sent}_{i}=a+\sum_{\mathrm{j}} \beta_{j} D_{j}+\varepsilon i,
$$

where senti is the inflation sentiment variable (perc_ind or exp_ind) of individual $i$ and $D_{j}$ is a set of dummy variables for each socio-demographic characteristic. That way an average relationship between the observed variables is obtained, with the results given in Table 5.9

\begin{tabular}{llcc}
\hline & & Percind & Exp_ind \\
\hline \multirow{4}{*}{ Gender } & Constant & $16.7573^{* * *}$ & $15.5261^{* * *}$ \\
& & {$[F=0.3682]$} & {$[F=0.0908]$} \\
& Female & $r$ & $r$ \\
Education & Male & -0.5731 & -0.2632 \\
& & {$[F=1.9081]$} & {$\left[F=3.1976^{* *}\right]$} \\
& Primary & $r$ & $r$ \\
Income & Secondary & -0.0788 & -0.5560 \\
& Further & -2.6939 & $-3.3973^{*}$ \\
& & {$\left[F=3.8068^{* *}\right]$} & {$\left[F=3.5220^{* *}\right]$} \\
& $Q 1$ & $-5.0471^{* *}$ & $-4.6697^{* *}$ \\
& $Q 2$ & $-3.8039^{*}$ & $-2.8186^{*}$ \\
Age & $Q 3$ & $-3.7310^{* *}$ & $-2.1862^{\mathrm{a}}$ \\
& $Q 4$ & $r$ & $r$ \\
& & {$[F=1.1311]$} & {$\left[F=3.5220^{* *}\right]$} \\
& $15-29$ & $r$ & $r$ \\
& $30-49$ & 0.9388 & 0.9615 \\
& $50-64$ & $2.4555^{\mathrm{a}}$ & $2.6774^{*}$ \\
& $65+$ & 1.8202 & -0.3966 \\
\hline
\end{tabular}

Note: $r$ denotes the particular category's reference group. The values in square brackets denote the Wald test F-statistics, restricting all dummy variables in a particular category to zero.

${ }^{*} \mathrm{p}<0.05 ;{ }^{* *} \mathrm{p}<0.01 ;{ }^{* *} \mathrm{p}<0.001 ;{ }^{\mathrm{a}} \mathrm{p}<0.1$

These results corroborate exactly the same sentiment tendencies in terms of age, education and income. Surprisingly, high education significantly feeds into consumers' inflation sentiment only in terms of perceptions.

Combining these results for the income and education variables with those from Tables 2, 3 and 4, it is possible to conclude that the first hypothesis is partially valid: the hypothe- 
DRUŠ. ISTRAŽ. ZAGREB GOD. 22 (2013), BR. 1, STR. $1-21$

SORIĆ, P., ČIŽMEŠIJA, M.: PRICE SENTIMENT..

TABLE 6

Associativeness heuristic test results sis can be verified according to the ANOVA and post-hoc procedures, yet within the regression framework the educational influence on inflation perceptions is not significant. This, however, is partially due to the differing methodology of measuring the inflation sentiment (balance statistic vs. the individual answers).

The evidence regarding the third hypothesis is rather firm: pre-retirement consumers (with considerable hyperinflation experiences) indeed produce significantly more biased inflation estimates than other age groups.

The gender heterogeneity is not proven significant, yielding the conclusion that the third hypothesis cannot be verified.

In order to empirically question the associativeness heuristic in the context of inflation sentiment, a dummy regression model is estimated with perc and $\exp$ (for the total sample) as the dependent variables, separately. The dummy variable value is set to 0 prior to the economic crisis and 1 throughout the crisis period. ${ }^{10}$

\begin{tabular}{ll}
\hline Perc & Exp \\
\hline-0.571 & $11.713^{* * *}$ \\
{$[F=0.1038]$} & {$\left[F=16.0827^{* * *}\right]$}
\end{tabular}

The values in square brackets denote the Wald test F-statistics, restricting all dummy variables in a particular category to zero. ${ }^{*} \mathrm{p}<0.05 ;{ }^{* *} \mathrm{p}<0.01 ;{ }^{* *} \mathrm{p}<0.001$

The premise here is that consumers associate the hyperinflation in the early 1990s with a concurrently high level of economic uncertainty. And indeed, contradicting the deflationary pressures in the recent crisis, consumers record significantly higher expected inflation rates than in the period of stable economic growth (at the 5\% significance level). On the other hand, the difference in inflation perceptions is not significant at the conventional levels. Therefore the fourth hypothesis is confirmed only for the inflation expectations.

\section{CONCLUSION}

This paper offers an empirical assessment of the differences in consumers' inflation sentiment with regard to their main socio-demographic characteristics. Relying on the best practice of CS research, two separate indicators of perceived and expected inflation were extracted: balance of responses as the aggregate measure of inflation sentiment and individual consumers' estimates of the perceived and expected inflation rates. Using ANOVA analysis, t-test and dummy variable regressions, significant differences were found with regard to 
DRUŠ. ISTRAŽ. ZAGREB GOD. 22 (2013), BR. 1 STR. 1-21

SORIĆ, P., ČIŽMEŠIJA, M.: PRICE SENTIMENT...

age, educational attainment and income, while gender was not proven to be a good predictor of consumers' inflation sentiment. Particularly important, behavioural heuristics were taken into account when explicating these findings. The associativeness heuristics seems to apply well to inflation perceptions, meaning that people relate recent economic turbulences to hyperinflation. Also, the availability heuristic is useful in explaining the phenomenon that consumers with hyperinflation experiences tend to have severely upward biased inflation sentiment. These findings should entail specific retail trade policies in a sense that they stimulate the retailers to considerably reduce the prices of product groups associated with the consumer groups who overly accentuate their inflation perceptions. Such actions might prevent a severe downfall of their aggregate consumption. Lastly, it is found that the relationship between the education level and inflation sentiment bias is reversely proportional. This has strong policy implications since the increased availability of both formal and informal economic education would then lead to more efficient allocation of resources, making rational decisions about saving and investing, reduction of the unions' pressure on nominal wage growth and to the enhancement of social stability in the broadest context.

\section{NOTES}

1 The necessity of exploring consumers' sentiment stems from the convincing evidence that the incomes and stock market indexes of individual countries is heavily influenced not only by the economic sentiment of its citizens, but also by the global sentiment. This is specially accentuated by the process of economic and financial integration (Belke, Beckmann, \& Kühl, 2011, 2012).

2 Real inflation is usually measured by the Consumer price index (CPI) or the Harmonised index of consumer prices (HICP).

${ }^{3}$ It is important to notice that the numerical values of individual respondents' age and income is not being examined by the CS, but merely their belonging to a particular age/income group.

4 Two alternative approaches for estimating the aggregate inflation sentiment are present in the literature: the nonlinear regression method and the Carlson and Parkin method. Both approaches are often criticized for their too-restrictive assumptions (Nardo, 2003; Bra-

${ }^{5}$ A similar tendency is observable in the political business cycle literature: conservative governments (associated with the large holders of nominal claims) tend to be more inflation averse, whereas the social-liberal governments place more weight on fighting unemployment to protect the interests of the economically endangered segments of society (Belke \& Potrafke, 2012).

6 The sample is divided in three groups with respect to work: employed, unemployed and not in the labor force. chinger, 2008), and therefore will not be applied here. 
DRUŠ. ISTRAŽ. ZAGREB GOD. 22 (2013), BR. 1, STR. 1-21

SORIĆ, P., ČIŽMEŠIJA, M.: PRICE SENTIMENT...
7 It is important to highlight the study of Kahneman and Tversky (1974). They introduced a series of psychological experiments which proved the prevailing concept of rational homo economicus to be empirically invalid.

8 One-way ANOVA analysis and the t-test are based on two assumptions: homogeneity of variances and the normality of the sampling distribution. Levene's test is applied here before the empirical analysis, and it is validated that the variances can be characterized as homogeneous $(p<0.05)$ for every observed variable except education. Thus the Welch test is applied in order to take into account the heterogeneity of variances. On the other hand, due to the large sample, the sampling distribution normality is guaranteed by the Central Limit Theorem.

${ }^{9}$ Apart from the average inflation, the median inflation is also inspected as a plausible criterion to choose the representative month (median inflation of $2.65 \%$ is found in May 2009). The results are quite similar to those from Table 5, so they are left out due to space scarcity. 10 The breakpoint date is set to September 2008 due to the Lehman Brothers bankruptcy.

Antonides, G. (2008). How is perceived inflation related to actual price changes in the European Union? Journal of Economic Psychology, 29(4), 417-432. doi:10.1016/j.joep.2008.04.002

Anušić, Z., Rohatinski, Ž., \& Šonje, V. (1995). A road to low inflation: Croatia 1993/1994. Zagreb: Government of the Republic of Croatia.

Belke, A., \& Potrafke, N. (2012). Does government ideology matter in monetary policy? A panel data analysis for OECD countries. Journal of International Money and Finance, 31(5), 1126-1139. doi:10.1016/j.ji monfin.2011.12.014

Belke, A., Beckmann, J., \& Kühl, M. (2011). Global integration of Central and Eastern European financial markets - the role of economic sentiments. Review of International Economics, 19(1), 137-157. doi:10.1111/j.1467-9396.2010.00937.x

Belke, A., Beckmann, J., \& Kühl, M. (2012). The cross-country importance of global sentiments - evidence for smaller EU countries. International Economics and Economic Policy, 9(3-4), 245-264. doi:10. 1007/s10368-012-0216-5

Blanchflower, D. G., \& Kelly, R. (2008). Macroeconomic literacy, numeracy and the implications for monetary policy. Bank of England Working Paper.

Brachinger, H. W. (2008). A new index of perceived inflation: Assumptions, method and application to Germany. Journal of Economic Psychology, 29(4), 433-457. doi:10.1016/j.joep.2008.04.004

Bryan, M. F., \& Venkatu, G. (2001a). The demographics of inflation opinion surveys. Economic Commentary, Federal Reserve Bank of Cleveland (October 2001).

Bryan, M. F., \& Venkatu, G. (2001b). The curiously different inflation perspectives of men and women. Economic Commentary, Federal Reserve Bank of Cleveland (November 2001). 
DRUŠ. ISTRAŽ. ZAGREB GOD. 22 (2013), BR. 1, STR. $1-21$

SORIĆ, P., ČIŽMEŠIJA, M.: PRICE SENTIMENT...
Bukovšak, M. (2006). Anketa pouzdanja potrošača u Hrvatskoj (Consumer Surveys in Croatia). Istraživanja, No. 17, Zagreb: Hrvatska narodna banka.

Campbell, A., \& Katona, G. (1946). A national survey of wartime savings. The Public Opinion Quarterly, 10(3), 373-381.

Carroll, C. D. (2001). The epidemiology of macroeconomic expectations. NBER Working Paper 8695.

Čižmešija, M. (2008). Konjunkturni testovi Europske unije i Hrvatske (Tendency Surveys in the EU and Croatia). Zagreb: Privredni vjesnik.

Del Giovane, P., Fabiani, S., \& Sabbatini, R. (2008). What's behind "inflation perceptions"? A survey-based analysis of Italian consumers. Banca D'Italia Working Papers No. 655, January 2008.

European Commission (2007). European Economy. The Joint Harmonised EU Programme of Business and Consumer Surveys. User Guide updated 04/07/2007. Brussels.

Eurostat (2003). Euro changeover effects, Euro-indicators news release, June 18, 2003 [online]. Available at http://epp.eurostat.ec.europa.eu/ cache/ITY_PUBLIC/2-18062003-AP/EN/2-18062003-AP-EN.HTML

Evans, G. W., \& Honkapohja, S. (2001). Learning and expectations in microeconomics. Princeton NJ: Princeton University Press.

Forsells, M. and Kenny, G. (2004). Survey expectations, rationality and the ynamics of Euro area inflation. Journal of Business Cycle Measurement and Analysis, 1(1), 13-42.

Gabor, A., \& Granger, C. W. J. (1961). On the price consciousness of consumers. Journal of the Royal Statistical Society. Series C (Applied Statistics), 10(3), 170-188. doi:10.2307/2985208

Gnan, E., Langthaler, J., \& Valderrama, M. (2010). Shocks, the crisis and uncertainty about future inflation: Theory and evidence for the Euro area. Monetary Policy \& the Economy, Oesterreichische Nationalbank, 1, 26-52.

Gramlich, E. M. (1983). Models of inflation expectations formation: A comparison of household and economist forecasts. Journal of Money, Credit and Banking, 15(2), 155-173. doi:10.2307/1992397

Kahneman, D., \& Tversky, A. (1974). Judgment under uncertainty: Heuristics and biases. Science, New Series, 185(4157), 1124-1131.

Kokoszczyński, R., Łyziak, T., \& Stanisławska, E. (2006). Consumer inflation expectations: Usefulness of survey-based measures - a cross-country study. 28th CIRET Conference, Rome, September 2006.

Lindén, S. (2005). Quantified perceived and expected inflation in the Euro area - how incentives improve consumers inflation forecasts. Joint European Commission - OECD Workshop on International Development of Business and Consumer Tendency Surveys, Brussels, 14-15 November 2005.

Lombardelli, C., \& Saleheen, J. (2003). Public expectations of UK inflation. Bank of England Quarterly Bulletin, 43(3), 281-290.

Malešević Perović, L. (2010). Life satisfaction in Croatia. Croatian Economic Survey, 12(1), 45-81. 
DRUŠ. ISTRAŽ. ZAGREB GOD. 22 (2013), BR. 1, STR. 1-21

SORIĆ, P., ČIŽMEŠIJA, M.: PRICE SENTIMENT...
Mankiw, N. G., \& Reis, R. (2002). Sticky information versus sticky prices: A proposal to replace the New Keynesian Phillips curve. The Quarterly Journal of Economics, 117(4), 1295-1328. doi:10.1162/003355 302320935034

Mullainathan, S. (2002). A memory-based model of bounded rationality. The Quarterly Journal of Economics, MIT Press, 117(3), 735-774. doi:10.1162/003355302760193887

Nardo, M. (2003). The quantification of qualitative survey data: A critical assessment. Journal of Economic Surveys, 17(5), 645-668. doi:10. 1046/j.1467-6419.2003.00208.x

Nestić, D. (2010). The gender wage gap in Croatia - estimating the impact of differing rewards by means of counterfactual distributions. Croatian Economic Survey, 12(1), 83-119.

Palmqvist, S., \& Strömberg, L. (2004). Household inflation opinions - a tale of two surveys. Economic Review, 4, 23-42.

Penezić, D. (2006). Life satisfaction at adolescence and adulthood. Društvena istraživanja, 15(4-5), 643-669.

Pfajfar, D., \& Santoro, E. (2008). Asymmetries in inflation expectations formation across demographic groups. Cambridge Working Papers in Economics, No. 0824, University of Cambridge.

Sabrowski, H. (2008). Inflation expectation formation of German consumers: Rational or adaptive? Working Paper Series in Economics, No. 100, University of Lüneburg.

Simon, H. A. (1955). A behavioral model of rational choice. The Quarterly Journal of Economics, 69(1), 99-188. doi:10.2307/1884852

Traut-Mattausch, E., Schulz-Hardt, S., Greitemeyer, T., \& Frey, D. (2004). Expectancy confirmation in spite of disconfirming evidence: The case of price increases due to the introduction of the Euro. European Journal of Social Psychology, 34(6), 739-760. doi:10.1002/ejsp.228

\section{Cjenovni sentiment hrvatskih potrošača: pristranost proizašla iz kolektivnih sjećanja}

Petar SORIĆ, Mirjana ČIŽMEŠIJA

Ekonomski fakultet, Zagreb

Cili je rada identificirati razlike $u$ inflatornim percepcijama i očekivanjima između sociodemografskih skupina (s obzirom na dob, spol, dohodak i razinu obrazovanja). Navedena tema nije dosad adekvatno istražena u Hrvatskoj. Analiza se temelji na skupu podataka iz hrvatskih anketa pouzdanja potrošača, što ih je provodila Hrvatska narodna banka. Numerički pokazatelii percipirane i očekivane inflacije dobiveni su na dva zasebna načina: kao direktni odgovori ispitanika u anketi te kao salda odgovora na pitanja o percipiranim i očekivanim stopama inflacije u nacionalnom gospodarstvu. Obje vrste pokazatelja karakteriziraju značajne razlike $u$ inflatornom sentimentu između imućnih i 
DRUŠ, ISTRAŽ. ZAGREB GOD. 22 (2013), BR. 1 STR. 1-21

SORIĆ, P., ČIŽMEŠIJA, M.: PRICE SENTIMENT... socio-ekonomskih ugroženih skupina potrošača. Opažena divergencija posebno je izražena s obzirom na dohodak, dok su razlike s obzirom na spol zanemarive. Na temeliu bihevioralnih heuristika ponuđena su psihološka objašnjenja navedenih razlika. Heuristika raspoloživosti dokazana je kroz sklonost potrošača starije životne dobi (koji su u odraslom životu imali znatnih iskustava s hiperinflacijom) da generiraju osjetno viši inflatorni sentiment. Dokazano je i da hrvatski potrošači, u skladu s heuristikom asocijativnosti, povezuju recentno povećanje ekonomske neizvjesnosti s visokom inflacijom (baš kao u vrijeme hiperinflacije na početku 1990-ih godina).

Ključne riječi: percipirana inflacija, očekivana inflacija, bihevioralne heuristike, sentiment potrošača 